Int. J. Curr. Res. Med. Sci. (2017). 3(3): 72-75

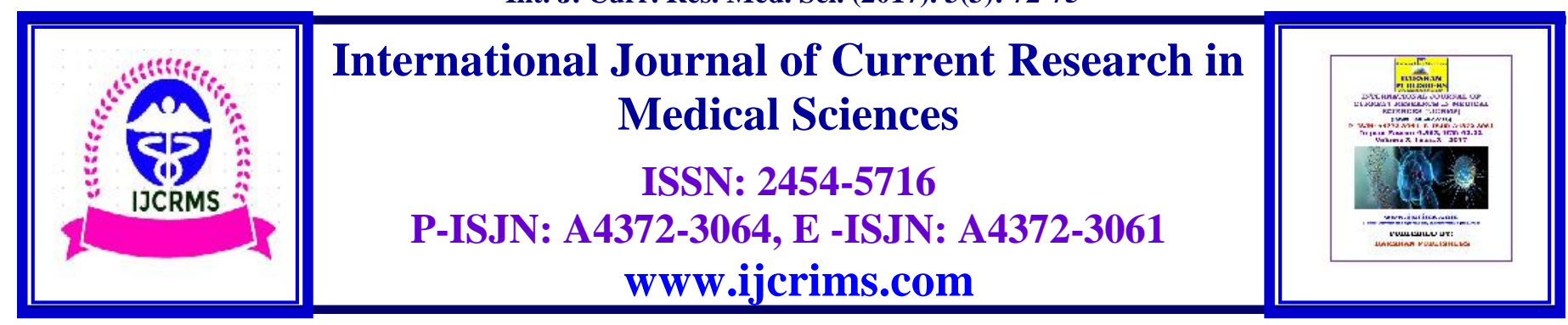

Case Report

Volume 3, Issue 3 -2017

DOI: http://dx.doi.org/10.22192/ijcrms.2017.03.03.009

\title{
Epidermal inclusion cyst of the thyroid gland: An uncommon entity.
}

\author{
Dr. Rachana Binayke ${ }^{1}$ and Dr. Kalpana. A.Deshpande ${ }^{2}$ \\ ${ }^{1}$ M.D. (Pathology), Assistant Professor, Grant Government Medical College, Mumbai- 400008 \\ ${ }^{2}$ M.D. (Pathology), Associate Professor, Grant Government Medical College, Mumbai- 400008 \\ Corresponding author: Dr. Rachana Binayke
}

E- mail: rbinayke@gmail.com

\begin{abstract}
Cystic lesions of the thyroid encompass a wide and heterogeneous spectrum ranging from degenerative, developmental, inclusion, non neoplastic, benign to malignant tumors with no particular age and sex predilection. The most common differential diagnosis of cystic lesions include branchial cleft cyst, colloid cysts, thyroglossal cysts, papillary carcinoma and very rarely epidermal cyst. Epidermal inclusion cysts can be defined as epithelial cysts which grow slowly. The treatment is total excision together with cyst's capsule. We report this case of thyroid epidermoid cyst at a rare site in a 26 year old female which was diagnosed accurately on cytology and confirmed on histopathological examination.
\end{abstract}

Keywords: Thyroid gland, Cystic lesion, Epidermoid cyst, Cytology, Histopathology.

\section{Introduction}

Diseases of the thyroid gland are common and comprise a spectrum of entities causing systemic disease (Grave's disease) or a localised abnormality in the thyroid gland such as nodular enlargement (goitre) or a tumour mass which can be solid or cystic. The surgical excision of the nodule and its histological examination is the only way to differentiate between the more frequent benign and much less frequent malignant nodules. ${ }^{1}$

Fine Needle Cytology (FNC) has proven to be a first line tool to evaluate the thyroid lesions because of its cost effectiveness and high patient acceptance. ${ }^{2}$ The BETHESDA system of reporting for thyroid cytopathology has served useful in bridging discrepancy, bringing uniformity between pathologists and clinicians. ${ }^{3}$

Thyroid gland is a rare site for epidermal cyst occurrence. Although various theories have been suggested to explain etiology, its exact reason is still unclear. These can arise owing to squamous metaplasia of the glands. ${ }^{4}$ Only a few cases have been previously reported in the literature. We report such a case of epidermal cyst in its unusual location in thyroid gland in a 26 year old female. 


\section{Case History}

A 26 years old female presented with complaints of swelling in anterior part of neck and pain during swallowing since 6-7 months. The mass was solitary, firm and moved with deglutition. The CT scan impression was a well defined, unilocular, thin walled, peripherally enhancing, hypodense, cystic lesion in right lobe of thyroid extending to right half of isthmus and pyramidal lobe. Thyroid function test was within normal limits. A clinical diagnosis of nodular colloid goiter with cystic change was entertained. The mass was subjected for fine needle aspiration cytology and it revealed dirty white aspirate. The cytology smears revealed numerous nucleate and anucleate squamous cells along with scattered inflammatory cells against dirty background. There was no evidence of atypia or malignancy .The cytology was reported as benign category with a suspicion of infected epidermoid cyst as per the BETHESDA system. We received specimen of hemithyroidectomy measuring $3 \times 2 \times 1.5 \mathrm{~cm}$, externally greyish brown. On cut section, a cyst measuring $1.5 \times 1.5 \mathrm{~cm}$ seen at one end containing whitish material. It was surrounded by normal thyroid tissue with minimal congestion. On histopathological examination, sections revealed thyroid tissue with lymphocytes scattered as well as in aggregation at few places along with a cyst wall lined by thinned out stratified squamous epithelium with keratin flakes. Just outside the cyst, band of fibrosis with foamy macrophages and occasional multinucleated giant cells were seen along with lymphocytes. The adjacent thyroid was unremarkable. A final diagnosis of epidermal inclusion cyst with foreign body giant cell reaction was rendered.

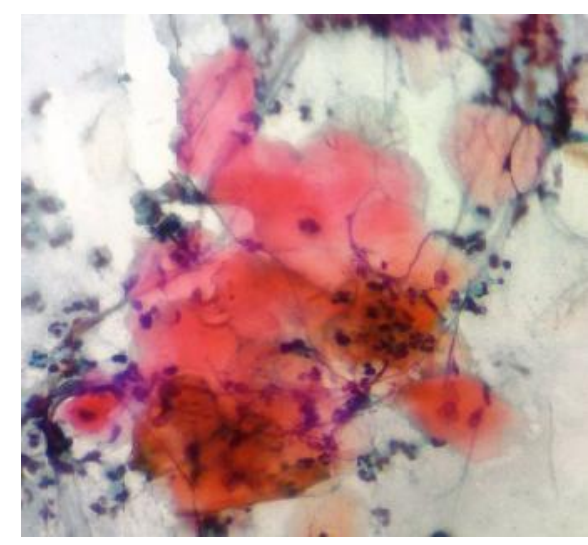

Fig 1 : Cytology smears showing anucleate and nucleate squames along with inflammatory cells against a dirty background (PAP stain)

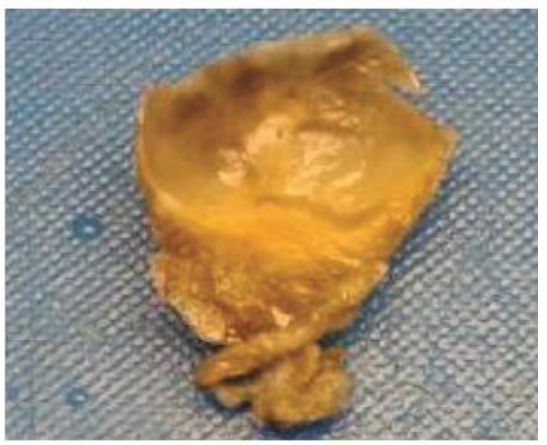

Fig 2 : Thyroidectomy specimen showing a unilocular cyst containing whitsh material 

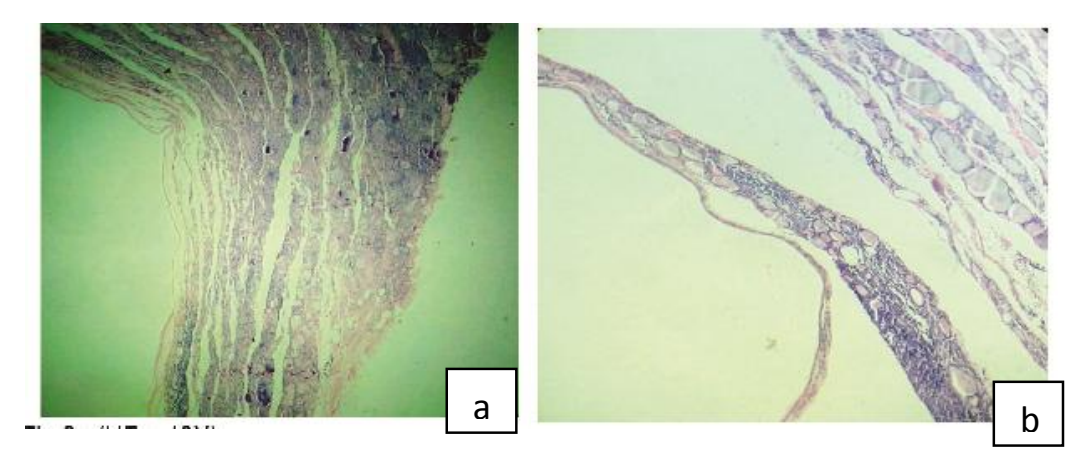

Fig 3 (a \& b): Cyst wall lined by stratified squamous epithelium containing few keratin flakes and surrounded by band of fibrosis and inflammatory infiltrate. (H \& E stain)

\section{Discussion}

Squamous epithelium first reported by Nicholson in $1922^{5}$ is undoubtedly an unusual finding in the human thyroid gland. He attributed this finding to metaplasia of the follicular epithelium induced by severe chronic inflammatory and fibrotic changes in the gland. ${ }^{4,5}$ Epidermoid inclusion cysts are ubiquitous in the body but rarely encountered entity in the thyroid gland. The rarity is highlighted by the fact that only 8 cases of its occurrence have been reported in the literature. The age range was 4 to 60 years with a mean of 42 years. No sex predilection was noted. These cyst were unilocular and well circumscribed with size ranging from 1.1 to $4.4 \mathrm{cms}$. The location of the cyst was in the right lobe in 4 patients, in the left lobe in 3 patients and the isthmus in 1 patient. ${ }^{6}$ The cytology smears revealed many anucleate squames, mature squamous cells and clusters of inflammatory cells comprising of neutrophils, lymphocytes and macrophages against dirty background. Histopathologically they were lined by squamous epithelium and surrounded by a fibrous layer, which might contain smooth muscle fibers along with clusters of atrophic follicles. ${ }^{7}$ The treatment of choice is total surgical resection of the cyst along with its' capsule. The cases reported in literature do not document the recurrence of the lesion once excised completely. ${ }^{8}$

\section{Conclusion}

The drive home message from this case report is that since squamous cells are not a component of normal thyroid gland,their presence should make one think of a variety of thyroid lesions such as benign metaplasia, neoplasms, congenital remnants such as thymic rests, thyroglossal duct remnants, brachial cleft cysts and epidermoid cysts $^{9}$ though encountered infrequently. In such cases clinical features along with radiological correlation is essential. Cytology along with histopathology examination forms the gold standard for diagnosis of such rare lesions.

\section{Funding: None}

Conflict of interest: None declared

\section{References}

1. Mitra A, Abbas AK. The endocrine system. In: Robbins and Cotran Pathologic Basis of Disease, 8th edn. Kumar V, Abbas AK, Fausto N, Aster JC (eds). Philadelphia: Saunders 2010:1097- 1164.

2. Handa U, Garg S, Mohan H et al. Role of Fine Needle aspiration cytology in diagnosis and management of thyroid lesions; A study of 434 cases. Journal of cytology 2008; 25: 1316.

3. Edmund S. Cibas, Syed Z. Ali.The Bethesda System for Reporting Thyroid Cytopathology Am J Clin Pathol 2009;132:658-665

4. J.N.Harcourt-Webster.Squamous epithelium in the human thyroid gland. J.clin. Path. 1966,19:384-388.

5. Nicholson, G.W .Guy's Hosp.Rep 1922:72-75 
Int. J. Curr. Res. Med. Sci. (2017). 3(3): 72-75

6. Woseneneh Bekele, Eugenio O. Gerscovich, Sima Naderi et al. Sonography of an Epidermoid Inclusion Cyst of the Thyroid Gland; J Ultrasound Med 2012 ; 31 (1): 128129

7. Chen KTK. Fine-needle aspiration cytology of epidermoid cyst of the thyroid: report of a case and review of seven cases. Diagn Cytopathol 2007; 35:123-124.

8. Ozan Kuduban. Epidermal Inclusion Cyst of Thyroid Gland. The Eurasian Journal of Medicine 2014; 47(1):7

9. LiVolsi VA, Merino MJ. Squamous cells in human thyroid gland. Am J Surg Pathol 1978; 2:133-140.

\begin{tabular}{|c|l|}
\hline \multicolumn{2}{|c|}{ Access this Article in Online } \\
\hline Q & Website: \\
& www.ijcrims.com \\
\cline { 1 - 1 } & Subject: \\
Quick Response Code & \\
\hline
\end{tabular}

How to cite this article:

Rachana Binayke and Kalpana. A.Deshpande. (2017). Epidermal inclusion cyst of the thyroid gland: An uncommon entity. Int. J. Curr. Res. Med. Sci. 3(3): 72-75.

DOI: http://dx.doi.org/10.22192/ijcrms.2017.03.03.009 